\title{
Flooding, flood risks and coping strategies in urban informal residential areas: The case of Keko Machungwa, Dar es Salaam, Tanzania
}

\begin{abstract}
Authors:
Tumpale Sakijege ${ }^{1}$

John Lupala ${ }^{2}$

Shaaban Sheuya ${ }^{3}$

Affiliations:

${ }^{1}$ Department of Regional

Development Planning, Ardhi

University, Tanzania

${ }^{2}$ School Dean, Department of Urban and Regional Planning, Ardhi University, Tanzania

${ }^{3}$ Department of Housing and Infrastructure Planning, Ardhi University, Tanzania

Correspondence to:

Tumpale Sakijege

Email:

tumpale@yahoo.com

Postal address:

PO Box 35176, Dar es

Salaam, Tanzania

Key Words:

Coping strategies; Informa

settlements; Climate change

Flooding; Risks; Disaster; Dar

es Salaam

\section{Dates:}

Received: Oct. 2011

Accepted: 11 May 2012

Published: 08 Aug. 2012

How to cite this article: Sakijege, T., Lupala, J. \& Sheuya, S., 2012, 'Flooding, flood risks and coping strategies in urban informal residential areas: The case of Keko Machungwa, Dar es Salaam, Tanzania', Jamba: Journal of Disaster Risk Studies 4(1), Art. \#46, 10 pages. $\mathrm{http}: / / \mathrm{dx}$.doi. org/10.4102/jamba.v4i1.46
\end{abstract}

C 2012. The Authors Licensee: AOSIS OpenJournals. This work is licensed under the Creative Commons Attribution License.
This article presents findings from a study carried out in Keko Machungwa informal settlement in Dar es Salaam under the auspices of the Disaster Management Training Centre of Ardhi University, Tanzania. The settlement has experienced frequent flooding in the past five years, and this study explores the causes, risks, extent of flooding and coping strategies of residents as well as municipality and city officials. Key methods employed in capturing empirical evidence included mapping of zones by severity of flooding, interviews with households, subward leaders, and municipal and city officials. Non-participant observation, primarily taking photographs, complemented these methods. Laboratory tests of water samples taken from shallow wells in the settlement were performed to establish the level of pollution. In addition, records of prevalence of water-borne diseases were gathered from a dispensary within the settlement to corroborate flooding events, water pollution and occurrence of such diseases. Findings show that flooding is contributed to by the lack of a coordinated stormwater drainage system; haphazard housing development within the valley; and blocking of the water stream by haphazard dumping of solid waste and construction. Risks associated with flooding include water and air pollution, diseases, waterlogging and blocked accessibility. The most common coping strategies at household level are use of sandbags and tree logs; raised pit latrines and doorsteps; provision of water outlet pipes above plinth level; construction of embankments, protection walls and elevation of house foundations; seasonal displacement; and boiling and chemical treatment of water. Recommendations for future action at household, community and city level are made.

\section{Introduction}

One of the most visible aspects of housing poverty in developing countries is the mushrooming of slums. UN-Habitat defines housing poverty as 'the individuals and households who lack safe, secure and healthy shelter with basic infrastructure such as piped water and adequate provision for sanitation, drainage and the removal of household wastes' (UN-Habitat 1996:109). Today one billion people out of the six billion world population lives in slums (UN-Habitat 2003). According to UN-Habitat (2006) a slum household is:

a group of individuals living under the same roof in an urban area who lack one or more of the following five conditions: access to improved water; access to sanitation; durable housing; sufficient living area; and secure tenure. (Emphasis in the original) (p. 19)

In Tanzania the word 'slum' is rarely used; the most commonly used expressions are 'informal' or 'unplanned' settlements. Informality of settlements essentially comes from the processes through which such settlements evolve, develop and consolidate. Unlike squatter settlements, which connote illegality in land-holding systems, informal or unplanned settlements in Tanzania are recognised by the authorities. Their informality emanates from development of houses which does not follow the laid-down official procedures (Lupala 2002; Kombe 1995). In this study the three terms slums, informal and unplanned settlements are used interchangeably.

It has been established that housing poverty and ill health are strongly interlinked (World Health Organization [WHO] 2008). This link was first established during the Industrial Revolution in Europe in the early 1800s, and the birth of modern urban planning is considered to be one of the early attempts to overcome the problem (Benevolo 1971).

As argued above, living in inadequate shelter and a poor environment is known to be a major cause of ill health. In developing countries the most common diseases include diarrhoea, malaria, acute respiratory infections such as pneumonia, cholera, dysentery, intestinal worms and tuberculosis (WHO 2008). However, ill health caused by living and working in slums should no longer continue to be the only lens through which life in slums is viewed. It is now known that factors such as climate change, particularly risks from flooding, water pollution and high temperatures, 
are increasingly making life in these settlements difficult. Satterthwaite et al. (2007, cited in Adelekan 2010:434) argue that very little attention has been paid to the vulnerability to climate change of urban low-income populations. Jabeen, Johnson and Allen (2010) observe that the effects of climate change will increase the vulnerability of the urban poor more than other groups of urban dwellers.

Studies from Latin America show that global climate change will manifest itself in temperature changes, variations in precipitation and wind variables, and these in turn will lead to an increase in the frequency and intensity of floods. Consequently, these changes will lead to increased incidences of vector-borne diseases (Inter-American Development Bank 2011). Furthermore, a recent report from the Intergovernmental Panel on Climate Change (Van Der Linden \& Hanson 2007) shows that projected trends in climate change will, amongst other things, increase malnutrition; disease and injury from heat waves, floods, fires, and droughts; and alter the range of some infectious disease vectors (Confalonieri et al. 2007, cited in Awuor, Orindi \& Adwera 2008:232). Regarding the latter, the report notes that the burden of diarrhoeal diseases will increase; the geographical range of malaria will expand in some regions and contract in others; and transmission seasons will alter (Confalonieri et al. 2007, cited in Awuor, Orindi \& Adwera 2008:232).

Dar es Salaam, the largest commercial city in Tanzania, is estimated to have a population of four million (UN-Habitat 2010a). Nearly $80 \%$ (3.2 million) of the population live in about 43 informal settlements of different sizes which have limited access to basic infrastructure services such as water supply, sewerage and stormwater drainage systems. Some of the settlements are regularly affected by devastating flooding whenever it rains. Inhabitants have continued to reside in these settlements despite flooding effects such as loss of human life, destruction of properties, environmental degradation, environmental pollution and disease outbreaks (Lerise \& Malele 2005).

For a number of years the world has been trying to significantly reduce the number of slum dwellers by 2020. The recent UN-Habitat report shows that a total of 227 million people in the developing world will have moved out of slum conditions in the 2000-2010 period, thus surpassing the Millenium Development Goal 7 slum target by at least 2.2 times, and 10 years ahead of the 2020 deadline (UN-Habitat 2010b:8). However, progress made '... has not been enough to counter the demographic expansion in informal settlements in the developing world' (UN-Habitat 2010b:8). The report further notes that the efforts to reduce the number of slums are neither satisfactory nor adequate.

Although this is the case, very few studies have explored the coping strategies of people living in informal settlements in the face of a combination of ill health caused by the nature of the living and working environment, on the one hand, and the risks from climate change on the other. It is argued that context-specific knowledge, that is, knowledge obtained from the lived experiences of the affected people, will greatly enhance our understanding of the locally grown urban coping strategies. To this end, this study aims to:

- explore why flooding takes place in informal settlements

- explain the risks associated with the floods

- explore the coping strategies used by the residents.

\section{Floods, risks, and coping strategies: An overview}

Climate change manifests itself in, amongst other things, storm occurrence and flooding. This problem is further compounded by unguided rapid urbanisation and limited capacity of urban local authorities to address this issue. For example, most of the informal settlements lack stormwater drainage channels that are designed and built to engineering standards. The lack of stormwater drainage channels in settlements that are rapidly densifying is a major cause of flooding. This is due to the fact that as densification increases, water run-off from the roofs of buildings alters the urban land cover and land surface, including blocking existing natural stormwater drains. Poor solid waste management in the settlements further complicates the problem.

In a study which covers urban poor settlements in Accra (Ghana), Kampala (Uganda), Lagos (Nigeria), Maputo (Mozambique), and Nairobi (Kenya), Douglas et al. (2008) provide a summary of the messages that emerge from flooding in urban areas:

- climate change which manifests in changing patterns of rainfall increases storm frequency and intensity and hence leads to flooding

- for the urban poor the impact of flooding is becoming more frequent and increasingly severe

- housing development in floodplains, inadequate waste management and lack of maintenance of stormwater drainage channels (where existent) further aggravate the flooding problem.

The question is: how do people living in informal settlements cope with these challenges? What will happen in the future if corrective measures are not taken?

According to Blaikie et al. (2004), coping strategies of the urban poor can be grouped into 'preventive' and 'impact minimising'. The former require people to make informed choices to avoid being affected by an event, a typical example being the decision to avoid building in flood-prone areas. Impact-minimising strategies, on the other hand, are those which minimise loss and facilitate recovery (Jabeen et al. 2010; Blaikie et al. 2004). Studies have further shown that coping strategies operate at different levels: individual (household), community (neighbourhood), and institutional (citywide).

The study by Douglas et al. (2008) which covered five cities in Africa also explored people's perceptions of the causes of flooding and their coping strategies. According to their study flood risks are caused by lack of adequate drainage coupled with poor management of existing drainage; the effects of unplanned and unregulated urban development; lack of attention to the problem by governments; and changes in the weather patterns. 
Regarding coping strategies, the main finding is that these largely depend on individual efforts, and that spontaneous community action to unblock drainage channels rarely takes place (Douglas et al. 2008). Some of the coping strategies include creating high spaces by using blocks, stones and furniture; blocking of water inlets using available materials; digging trenches around houses before and during floods; and boiling drinking water to minimise risks associated with water-borne diseases.

\section{Methodology \\ Research strategy}

A case study approach was used in carrying out this research primarily because a deeper understanding of the causes of and coping strategies to flooding were being sought. The choice of a case study settlement started with an inventory of all settlements affected by flooding in Dar es Salaam. A total of 17 settlements were identified.

\section{Data sources}

Both primary and secondary data sources were deployed in this research. This included a literature review, particularly of publications on the current debate on flooding and coping strategies at community and city level. A house count from aerial photos from 2005 revealed that there were approximately 84 houses located in the severely flooded area that covered approximately 5.07 hectares. A total of 30 from 84 houses were picked for interviews. This represented about $35.7 \%$ of all houses in the flooding zone. Household interviews were complemented with interviews with a subward leader, the sub-ward being the lowest organ of local governance in Tanzania.

Another method of data collection was mapping. This was deployed in identifying extent of flooding through contour analysis and subsequently zoning those areas as severe, moderate and without flooding effects. Non-participant observation by taking photographs was a complementary method used to capture events and scenes related to the physical effects of flooding and coping strategies adopted by the local community. In addition to these methods, samples of water from the shallow wells were taken and tested in the water laboratories at Ardhi University for their potability and pollution levels. The idea was to establish the correlation between water pollution and occurrence of water-borne diseases in the settlement. The pollution level of the water was also corroborated with records obtained from a dispensary located within the settlement. Interviews were held with Temeke municipal officials with a view to capturing coping strategies at municipal level.

\section{Research instruments}

The key research instruments for this study included questionnaires that were administered to the identified and selected households, base maps (with contour intervals of two metres) and aerial photos of the settlement which facilitated identification of houses and sites that were affected by flooding in the settlement. Aerial photos, a camera and a checklist of questions were other key instruments employed in data collection.

\section{Analytical methods}

Empirical evidence gathered from various sources was analysed using tables especially for quantitative data. Whilst geographical information systems software (Map Information) was used to designate flooding zones by severity of flooding, responses from people and local leaders were quoted directly, corroborating other evidence emerging from observation such as photos and maps. Results from laboratory tests were analysed using tables. At a more general level, empirical evidence from Dar es Salaam, particularly that on coping strategies, has been discussed in line with experience from other countries providing a basis for comparison.

\section{Site selection}

In order to identify and select an information-rich case, five criteria were developed upon which settlements were subjected to evaluation. Firstly, the settlement must have been experiencing frequent flooding in the past five years. Secondly, it revealed trends which showed that the problem of flooding was growing over the years. Thirdly, conflicts of interest between flood control measures and urban development in the settlement were present, and that conflict must have been widely reported in mass media (television, radio and newspapers). Fourthly, the case study settlement has not previously been widely documented. Fifthly, the residents are proactive in taking measures to contain the situation. On the basis of the above criteria Keko Machungwa was chosen as an appropriate case study settlement for the research.

\section{Keko Machungwa: Location and main characteristics}

The Dar es Salaam City region is composed of three municipalities: Kinondoni, Ilala and Temeke. Each municipality is autonomous, but administratively the three are coordinated by the Dar es Salaam City Council. The study area of Keko Machungwa is located in the Temeke Municipality about 3 $\mathrm{km}$ from the city centre.

According to the 2002 Population Census, Keko Machungwa had a population of 12517 , the settlement covers an area of 30.95 hectares, and at that time it had 1654 houses (United Republic of Tanzana 2003). Being an informal settlement, it has no designed stormwater drainage channels; those that exist are improvised, not coordinated, and individually provided. Piped water supply is unreliable and several households depend on underground shallow wells. Furthermore, there is no proper solid waste management system, and people dump solid and liquid wastes haphazardly in the valleys and natural drains. As in many of the informal settlements in Dar es Salaam and Tanzania in general, the majority of urban dwellers use pit latrines as the most reliable option for sanitation.

Although about $75 \%$ of the settlement does not experience flooding, the rest of the area can be subdivided into (1) most severely flooded and (2) moderately flooded areas. The most seriously affected area of the settlement is that between one and two metres above mean sea level. A topographic analysis of the settlement showed that this area covered 5.07 hectares, 
which constituted $16.37 \%$ of the total study area (see Figure 1). There were 76 houses in this area. During the peak hours of flooding water reaches a height of half to one metre above the ground floor. During the rainy season the area gets filled up with water from within and outside Keko Machungwa. The water seriously affects houses built along the valley. The area that was moderately flooded covers 2.84 hectares and lies between two and four metres above mean sea level. There were 130 houses in this area.

\section{Findings \\ Causes of flooding}

The main factors which contribute to flooding in Keko Machungwa settlement are lack of a comprehensive stormwater drainage system; encroachment on river valley by haphazard construction of warehouses (e.g., by Ruby Road Ways and Oil Com Company) and housing development; and haphazard dumping of solid waste.

\section{Lack of stormwater drainage system}

Keko Machungwa settlement has no comprehensive stormwater drainage system; any existing ones have been constructed individually and in an uncoordinated manner. Whilst this area receives stormwater from areas within and outside Keko Machungwa settlement, the existing drainage channels are too narrow and shallow to accommodate water from upstream catchment areas. Besides the lack of a stormwater drainage system, the settlement has a high water table that exacerbates flooding during the rainy season.

Household interviews conducted in the settlement have shown that $90 \%$ of the houses use pit latrines for sanitation. The combination of a high water table and the use of pit latrines results in frequent filling up of the pits when it rains heavily (see Figure 2).

Waste water from pit latrines becomes a serious health hazard during the rainy season, because people also empty their pit latrines into the flooding water. In this way human excreta spread throughout the settlement. Since several households use underground water for domestic purposes, they are likely to be vulnerable to water-borne related diseases such as cholera, malaria and bilharzia.

Apart from pollution caused by haphazard excreta disposal, water from elevated parts of the settlements usually flows with a lot of solid waste. A distinctive characteristic of this water is that it smells bad and blocks downstream drainage systems. The bad smell is worsened by waste water and the rotting solid waste that get deposited in the low-lying part of the settlement.

The observed effects caused by the flooding water included damage to foundations of houses; displacement of six households to other parts of the city to seek temporary accommodation; and disruption of livelihood activities such as renting. As the owner of one house complained:

'Despite the protection wall, water still penetrates the house through the floor. My tenants left the house after realising this problem; I am planning to raise the foundation and floor after this rainy season.' (Participant A, Male, Petty trader, 51)

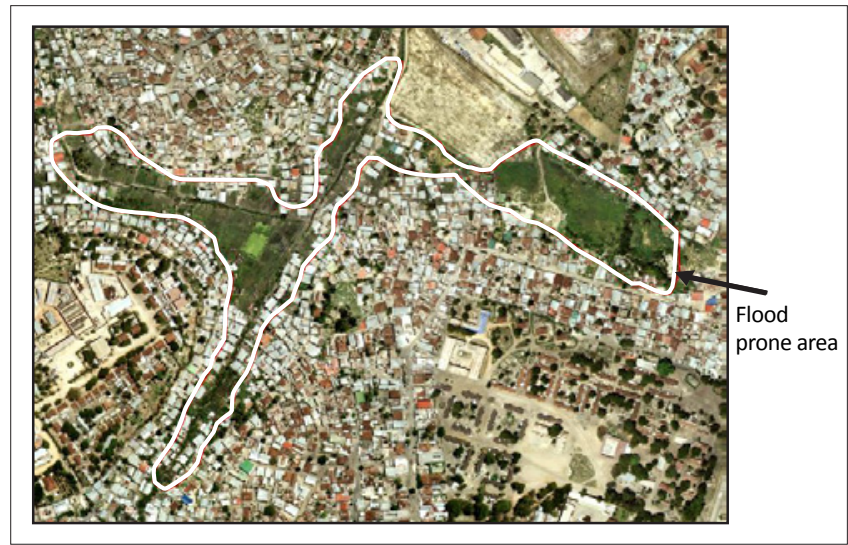

Source: Tumpale Sakijege, John Lupala, Shaaban Sheuya, 2008

FIGURE 1: Aerial photo showing flood-prone areas.

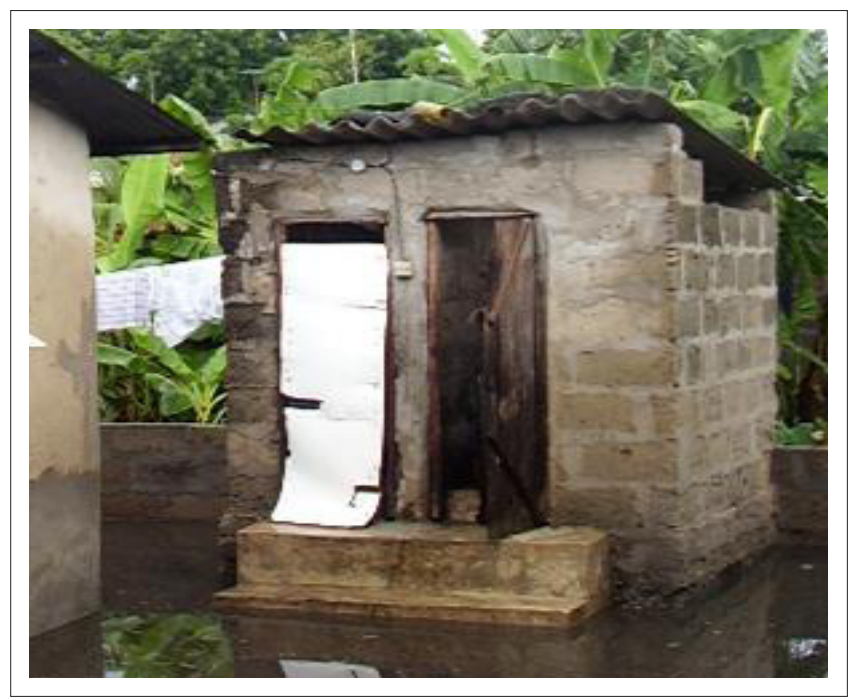

Source: Field work in Keko Machungwa, May 2009

FIGURE 2: A pit latrine surrounded by stagnant water during rainfall season.

\section{Encroachment on river valley}

Haphazard construction of warehouses and housing has aggravated flooding in Keko Machungwa. Examples of this phenomenon are warehouses built by Ruby Road Ways and Oil Com Company. Ruby Road Ways has constructed a warehouse across the Keko stream, leaving a small hole for stormwater. Similarly, Oil Com Company has reclaimed part of the river valley by filling up part of a plot with soil and then constructing a wall (see Figure 3).

The reclamation of land and construction of a wall necessitated shifting the river course from its original natural path towards residential areas. The partial blocking and shifting of the stream contributes substantially to flooding of the surrounding residential areas of Keko Machungwa.

\section{One of interviewed residents said:}

'Very few houses were affected by floods before the construction of these warehouses in 2005. However, the construction of these two warehouses has aggravated the flooding problem especially to those living along and within the valley. When it rains, flooding water rises as high as up to the windowsill level'. (Participant B, Male, Mason, 60) 
Although the owner of Ruby Road Ways provided a hole reinforced with some iron bars for stormwater to pass through, the size of the hole was too narrow to accommodate the huge volume of stormwater (see Figure 4).

As a result, when it rains heavily part of the stormwater flashes back to the settlement. The owner of the company explained that he had designed a small hole in order to prevent solid waste from entering his premises. In fact, when it rains heaps of uncollected solid waste accumulate and get deposited outside the wall. The accumulated waste completely blocks the hole, to the extent that stormwater can hardly pass through it. Therefore, the blocking of the natural drainage system and poor design and construction of the hole affect the majority of low-income people whose houses are in the severely flooded low-lying zone.

Regarding house construction, the study found this activity reduced the width of the stream, and in so doing water remains stagnant in the settlement for almost six months. In the hot and humid climatic conditions of Dar es Salaam, the stagnant water pools become breeding grounds for mosquitoes and other pathogens. As we shall see later in the forthcoming sections, water-borne diseases and malaria in particular persist in Keko Machungwa throughout the year.

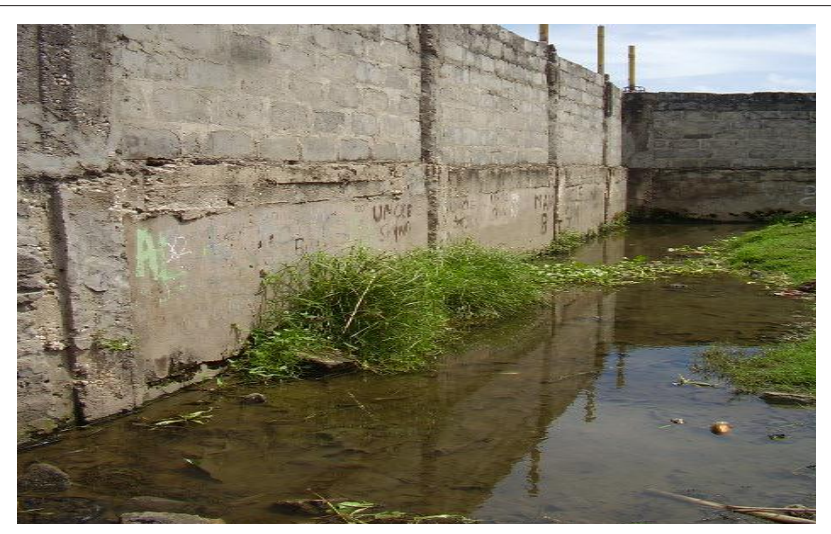

Source: Field work in Keko Machungwa, May 2009

FIGURE 3: Wall constructed by Ruby Road Ways on top of the stream, blocking the natural course of the river.

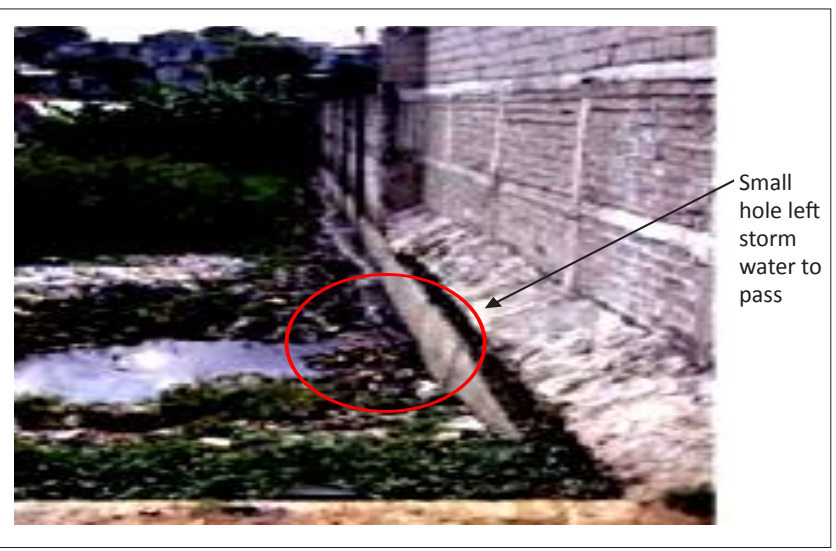

Source: Field work in Keko Machungwa, May 2009

FIGURE 4: Wall constructed by Oil Com Company blocking natural water flow.

\section{Haphazard dumping of solid waste}

As mentioned earlier, the existing stormwater drains in Keko Machungwa are improvised, not coordinated and individually provided. The area which is severely flooded has small natural streams, which cannot drain stormwater away from the houses. In addition, due to lack of proper solid waste management residents dispose waste into the drains and natural streams, contributing further to the increase in flooding when it rains heavily.

Accumulated solid waste starts to decompose and leach. The leaching wastes usually end up mixing with underground water. Hazards caused by leaching were noted to be both surface water and groundwater pollution. As reported earlier, many residents use groundwater for different purposes. During severe flooding the water wells are totally submerged and the shallow wells get filled up with stormwater which is mixed with raw and untreated human excreta and solid waste.

\section{Risks associated with flooding}

From the findings above, the risks associated with flooding include water and air pollution, diseases, waterlogging and blocked accessibility.

\section{Water and air pollution}

Both groundwater and surface water pollution were found to be significant in Keko Machungwa. The shallow wells were easily polluted by flooded pit latrines and crude disposal of liquid waste from toilets. Crude dumping of solid waste and poor management also contributed to ground and surface water pollution.

In order to substantiate the water pollution issue samples of water were taken from some water sources (particularly stream boreholes) for laboratory tests. The laboratory tests were carried out on only one parameter, namely presence of 'faecal coliforms', and this was adequate to establish the extent to which water sources in the settlement were polluted by waste that came with the floods.

Faecal coliforms are bacteria that are naturally present within the bodily waste of all warm-blooded animals. The presence of faecal coliforms usually indicates extent of contamination of groundwater by human sewage or animal droppings, which could contain other bacteria, viruses, or disease caused by micro-organisms. Table 1 shows results of the laboratory tests regarding water pollution levels.

The results show that water from streams had larger amounts of faecal coliforms (59 counts $/ 100 \mathrm{~mL}$ ) compared to borehole water (14 counts $/ 100 \mathrm{~mL}$ ). For total coliforms (other types of bacteria) water from streams had 70 counts $/ 100 \mathrm{~mL}$ whilst boreholes had 23 counts $/ 100 \mathrm{~mL}$. 
The WHO Drinking Water Quality Guidelines (1993) require that there should be no faecal coliforms at all in water. These results therefore indicate the presence of pathogens causing infectious disease such as cholera, dysentery and typhoid fever after drinking contaminated water. The risks of being infected with such diseases correlated with the level of contamination of the water and the amount of contaminated water consumed. Higher concentrations of Escherichia coli in water will indicate higher risk of contracting water-borne disease, even if small amounts of water are consumed. These results generally show that residents of Keko Machungwa settlement were at higher risk of contracting water-borne diseases.

Air pollution was manifested in an unpleasant smell as a result of rotting waste in the streams and in the settlement. This unpleasant condition was affecting almost all households in the study area.

\section{Diseases}

Diseases in the settlement are manifestations of disaster risks that are likely to be caused by an unhealthy and polluted living environment. According to the 2006 municipal council records, respiratory (coughing, pneumonia, and tuberculosis) as well as water-borne diseases (diarrhoea, cholera and typhoid) were the most common diseases affecting the majority of residents in Temeke Municipality. The main causes of these diseases were associated with the use of polluted water, poor sanitation and poor solid waste management systems. Children were more vulnerable as they used to play in stagnant contaminated and polluted water.

Statistics from Tyma dispensary, which is located in the settlement, revealed prevalence and persistence of reported cases of malaria, urinary tract infection, diarrhoea, schistosomiasis and typhoid. Higher frequencies were reported during the months of March, April and May, which is the period of heavy rainfall in Dar es Salaam (see Table 2).

\section{Waterlogging and blocked accessibility}

It was observed that waterlogging did not only occur in the severely and moderately flooded areas but also on the flat areas with congested houses and where drainage channels were non-existent. This resulted in the blocking of both vehicular and pedestrian accessibility to these houses (see Figure 5). Some residents passed through this water barefoot, fearing destroying their shoes, this action also likely to cause diseases.

\section{Coping strategies}

The coping strategies found in the settlement are at two levels: the household and the community.

\section{Coping strategies at household level}

The most common coping strategies at household level included use of sandbags and tree logs; water boiling and chemical treatment of water; raised pit latrines and
TABLE 1: Laboratory test results of water pollution.

\begin{tabular}{llccc}
\hline Parameter tested & Unit & \multicolumn{2}{c}{ Results } & \multirow{2}{*}{$\begin{array}{l}\text { WHO } \\
\text { Standards }\end{array}$} \\
\cline { 3 - 4 } & & Borehole & Stream & \\
\hline Faecal coliforms (E. coli) & Count $/ 100 \mathrm{~mL}$ & 14 & 59 & 0 \\
Total Coliform & Count $/ 100 \mathrm{~mL}$ & 23 & 70 & 0 \\
\hline
\end{tabular}

Source: Environmental Engineering Laboratory, Ardhi University, May 2009

TABLE 2: Trends in selected water-related diseases (March-May, 2009).

\begin{tabular}{lcccc}
\hline Diagnosis & March & April & May & Total \\
\hline Malaria & 31 & 52 & 39 & $\mathbf{1 2 2}$ \\
Urinary tract infection & 33 & 44 & 30 & $\mathbf{1 0 7}$ \\
Diarrhoea & 11 & 22 & 20 & $\mathbf{5 3}$ \\
Schistosomiasis & 5 & 9 & 7 & $\mathbf{2 1}$ \\
Typhoid & 4 & 7 & 6 & $\mathbf{1 7}$ \\
\hline Total & $\mathbf{8 4}$ & $\mathbf{1 3 4}$ & $\mathbf{1 0 2}$ & $\mathbf{3 2 0}$ \\
\hline
\end{tabular}

Source: Tyma dispensary records, Keko Machungwa, May 2009
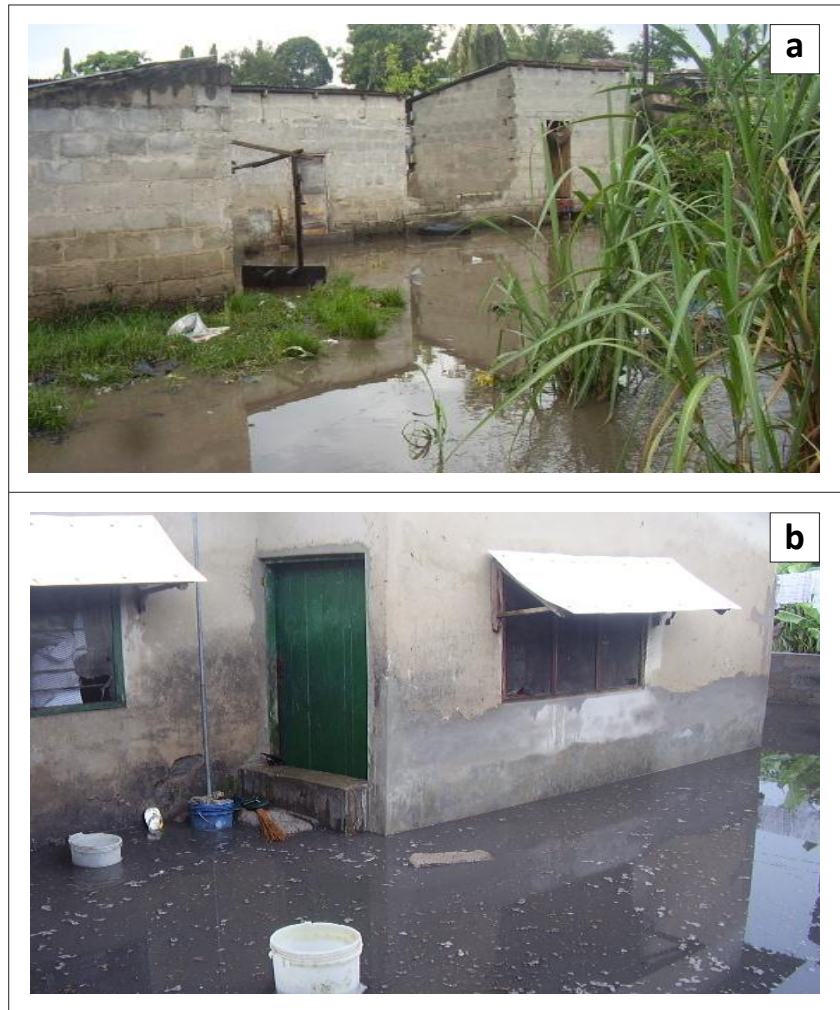

Source: Field work in Keko Machungwa, May 2009

FIGURE 5: Waterlogging (a) and blocked accessibility (b) to houses.

doorsteps; construction of protective walls and elevation of house foundations; seasonal displacement; and construction of pipe outlets above the house plinth level.

\section{Use of sandbags and tree logs}

The use of sandbags was meant to prevent erosion, provide accessibility and block flooding water, whilst tree logs were used to construct footbridges (see Figure 6). This strategy was, however, not suitable to resist heavy stormwater from heavy rainfalls, because the sandbags and tree logs were always washed away. Of the 30 interviewed households, 24 reported having been using sandbags to prevent flooding water from entering their houses. Children and old people found it difficult to use footbridges made from tree logs. 


\section{Water boiling and chemical treatment of water}

Regarding potable water, the main coping strategies used by individuals and households with regard to disease was limited to: (1) boiling of drinking water; and (2) use of chemical treatment such as 'water guard'. Of 30 respondents who were interviewed on how they treat water for domestic use, 17 said they boil water whilst 9 said that they used 'water guard'.

\section{Raised doorsteps and pit latrines}

As a result of flooding and the fluctuating water table, most households raised their doorsteps and pit latrine steps to prevent the stormwater from filling up their houses and pit latrines. Of 30 interviewed households, 15 had raised doorsteps to their houses and 14 had their pit latrines raised one metre above the plinth level. It was, however, noted that this strategy was also inadequate to cope with severe flooding (see Figure 7).

\section{Construction of protective walls and elevation of house foundations}

Wherever households had extra space around their houses, they built protective walls. Other households raised the foundation levels to prevent water from entering their houses. Although this solution helped individual houses, it largely blocked water flow during flooding. Also erosion caused some of the protective walls and houses to fall down. Protective walls were used by few households - only 6 out of the 30 interviewed. Since protective walls were constructed around the whole house flood water remained within the house compounds for long periods of time, resulting in other damage such as erosion of the foundations of buildings (see Figure 8).
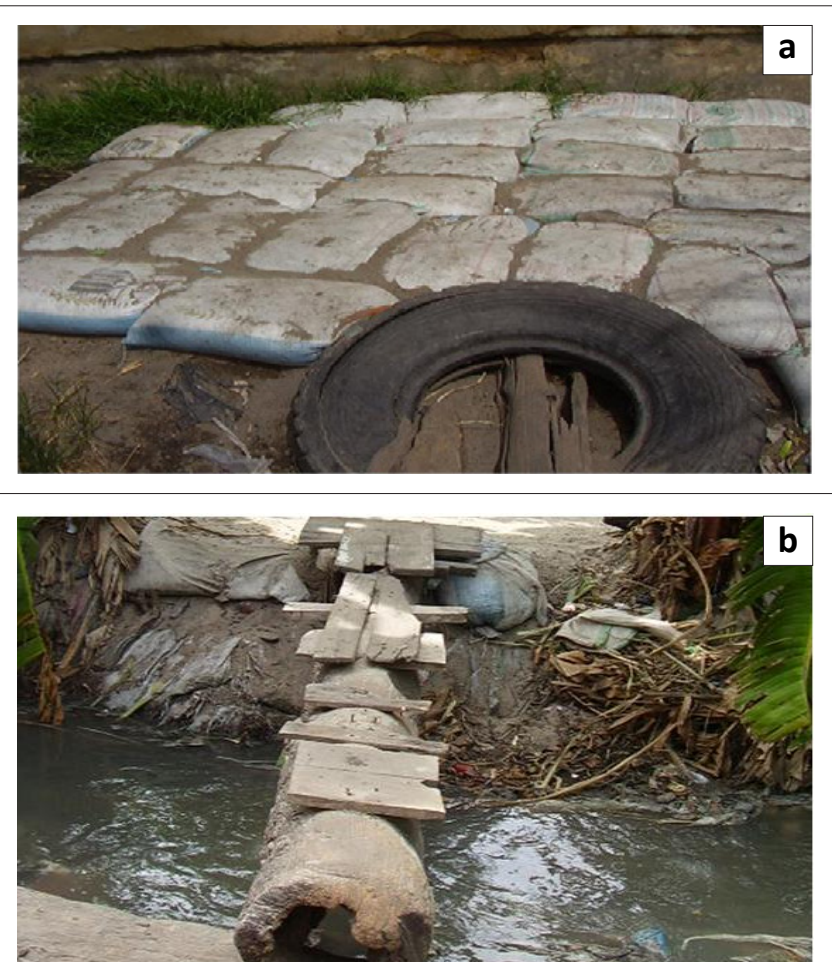

Source: Field work in Keko Machungwa, May 2009

FIGURE 6: Sandbags (a) used to prevent flooding and erosion (b).

\section{Seasonal displacement}

Some households temporarily moved away from the flooded settlement, especially during heavy rain seasons. Normally they sought refuge with their neighbours and relatives until such a time as water levels went down. This strategy was used by only two households out of the 30 who were interviewed. It is speculated that owner households were the ones who returned after the floods; many tenant households decided to move away from the area and sought alternative accommodation in settlements not affected by flooding. However, this aspect was not investigated in detail during the study.

\section{Provision of pipe outlets}

Water outlet pipes were built above the plinth level to drain off water. The most common pipes were of $20 \mathrm{~mm}-50 \mathrm{~mm}$ in diameter. These outlets reduced water to a certain extent, because during heavy rainfalls water entered houses through doors and other wall openings (see Figure 9). Only one household out of 30 used this particular strategy.
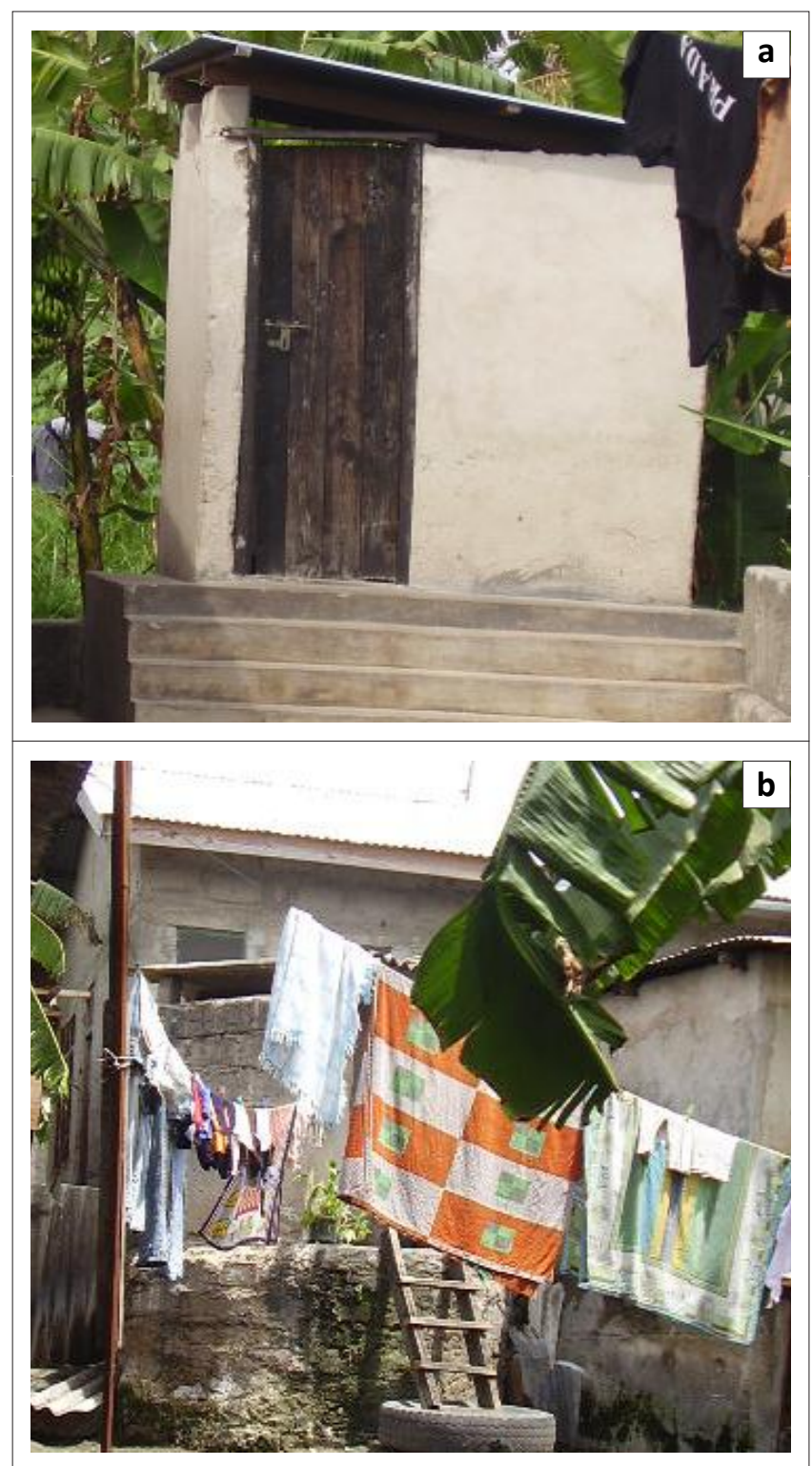

Source: Field work in Keko Machungwa, May 2009

FIGURE 7: (a) Pit latrines (b) raised from plinth level. 

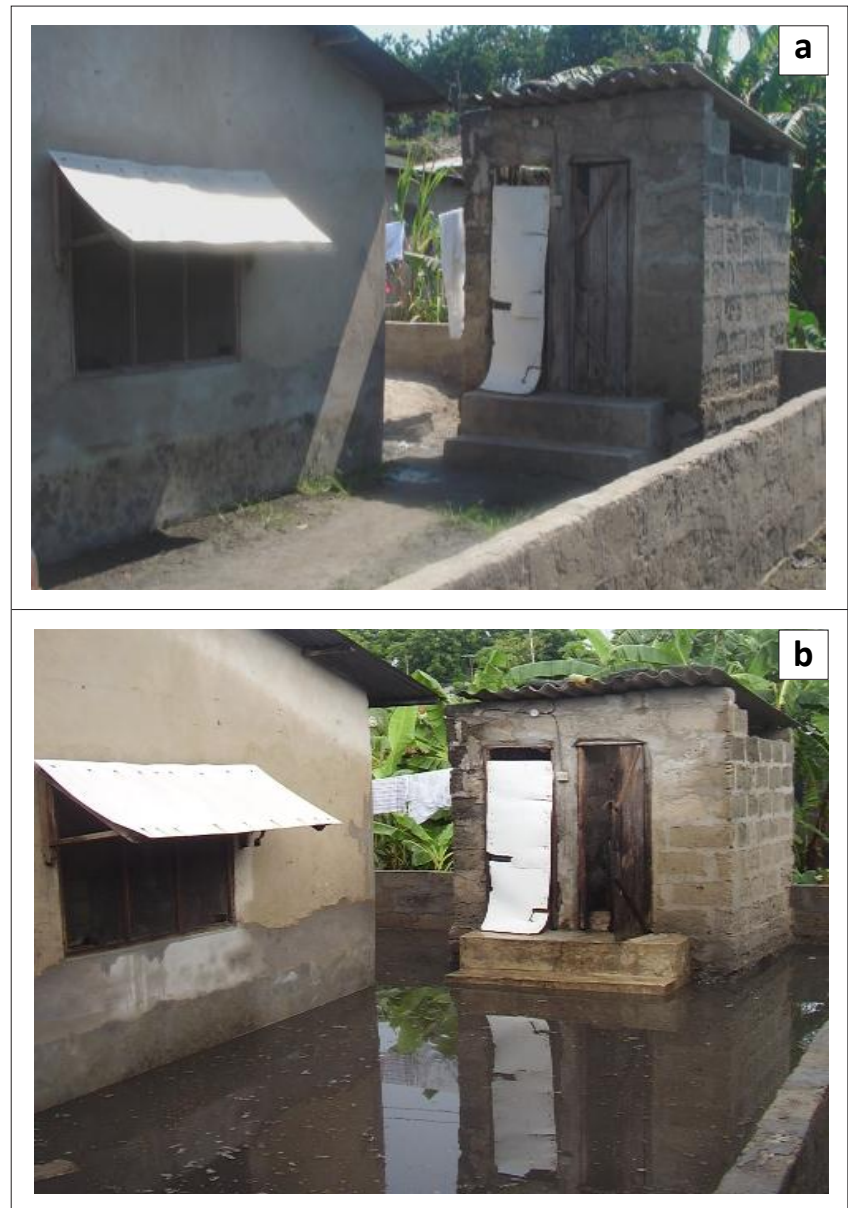

Source: Field work in Keko Machungwa, May 2009

FIGURE 8: Construction of protective walls (a) before rainfall and (b) after rainfall.

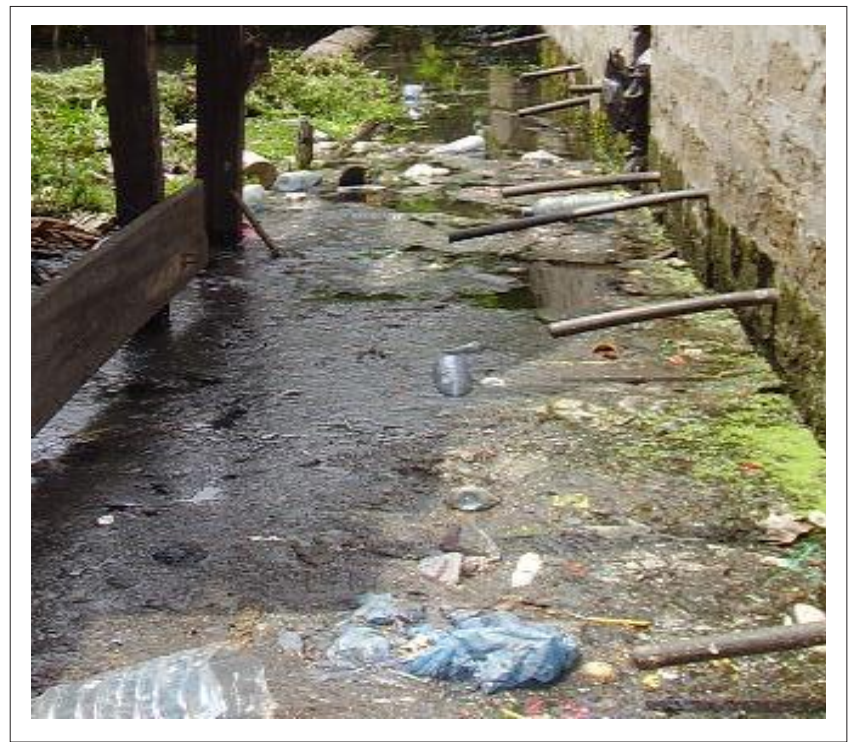

Source: Field work in Keko Machungwa, May 2009

FIGURE 9: Outlet pipes.

\section{Coping strategies at community level}

These included attempts to control housing development (including efforts to curb construction activities that block water streams), protesting, requesting companies to compensate the affected people, and instituting solid waste management practices.
TABLE 3: Summary of household coping strategies.

\begin{tabular}{ll}
\hline Coping strategy & $\begin{array}{l}\text { Respondents } \\
N=\mathbf{3 0}\end{array}$ \\
Use of sandbags and tree logs & 24 \\
Boiling water & 17 \\
Raised doorsteps & 15 \\
Raised pit latrines & 14 \\
Treating water with chemicals & 9 \\
Construction of protective walls and elevation of house foundations & 6 \\
Seasonal displacement & 2 \\
Construction of pipe outlets & 1 \\
\hline
\end{tabular}

\section{Controlling housing development}

In the year 2000 the sub-ward chairperson constituted a committee from the area whose main task was to see how they could cooperate with the Municipal Council to stop haphazard housing development in the settlement. More specifically, the committee wanted the local council to ask developers who had blocked the river to demolish those sections of their walls and warehouses which blocked the water course. The committee met with the Municipal Engineer several times, but no tangible action was taken to solve the problem.

In view of this, committee members decided to seek an audience with the City Engineer of the Dar es Salaam City Council. From the City Engineer the committee learnt that the two developers (who had built the warehouses and the wall across the stream) had a valid building permit. They were shocked and asked themselves how they could have building permits that allowed them to block natural streams.

\section{Protesting}

After these failures, some of the residents from Keko Machungwa and Kurasini under the leadership of their councillors and sub-ward leaders protested by holding demonstrations that were meant to force Ruby Roadways to increase the size of the hole through the wall so as to enable large amounts of storm water to pass through.

The owner of the investment never accepted the proposal from residents on the grounds that solid waste will enter his property. In view of this the sub-ward chairperson requested the Temeke Municipal Council to collect the accumulated solid wastes at Ruby warehouse wall. The council accepted and removed a total of 210 tonnes of solid waste from there. However, the size of the hole remained the same, despite repeated requests from people.

\section{Requesting companies to compensate affected people}

In another attempt the committee went to the City Engineer to ask for compensation of damages caused by flooding effects from the Oil Com Company. The committee was informed that since the company had a valid building permit, it would be almost impossible to accept compensation claims. However, the City Engineer, in an attempt to address people's claims, asked the developer to build a drainage channel. In principle the developer agreed to the request, but nothing had been done by the time this study was carried out in 2009. 
It therefore appears that efforts by the community were successful in informing the Municipal Council and the City Engineer of the magnitude of the problem, but not in terms of reducing flood risks. This is due to the fact that since 2000 (when the matter was reported) until 2009 when the study was carried out, developers were yet to rectify the situation and threats from floods continue to persist.

\section{Initiating solid waste management practices}

The sub-ward chairperson mobilised and convinced residents to pay Tshs 1000 (0.60 USD) per house (regardless of number of persons or households in it) per month to pay organised groups to collect waste from the area. Three such groups were identified, Keko Environmental, Keko Machungwa Mazingira Usafi and Keko Machungwa Usafi. Although the groups were ready to collect solid waste in the settlement, response from the residents was very low because very few contributed the agreed amount. As a result, the groups refused to continue working.

\section{Discussion}

Keko Machungwa settlement gets flooded even when rains are not heavy. As discussed in the foregoing sections, the main factors contributing to the flooding hazard and disasters are lack of a stormwater drainage system; encroachment on the river valley by haphazard construction of warehouses; housing development; and haphazard dumping of solid waste. It is interesting to note that these findings show major similarities with those identified in the study covering five African cities mentioned earlier (Douglas et al. (2008). What are not mentioned in Keko Machungwa are the factors related to weather changes; this is probably due to the fact that floods in the settlement are perceived as a temporary hazard. Severe flooding during heavy rainfall seasons culminated in a number of disaster risks, but at times the risks actualised into disasters. The risks include water and air pollution, diseases, waterlogging and blocked accessibility.

Individual households have attempted to use different coping strategies, most physical in nature. Similarly, the community attempted to put in place a number of community-level coping strategies, but little was achieved in addressing the long-term goal of controlling the flooding hazard and associated disasters in this settlement. Two reasons can be given for this failure: community-level attempts received little support from the municipal council, and flooding was perceived as a temporary problem in the settlement.

Therefore, except for similarities with the physical coping strategies at household level in the five African cities (Douglas et al. (2008), the community in Keko Machungwa (unlike those in the five cities) is quite active in trying to find possible community-level coping strategies. As a way forward, the strengths and potentials shown at household as well as community level need to be nurtured further.

\section{Conclusion and recommendations}

Right from the beginning of the study we argued that contextspecific knowledge on the causes of flooding, the associated risks and existing coping strategies is needed in order to guide future action. During the study we became aware that the residents of Keko Machungwa were not passive observers of the risks associated with the nature of their living environment and the effects of climate change and flooding in particular. The residents were trying their best to cope with the situation at household as well as community level. An analysis of the coping strategies at household level shows that they were essentially technical in nature. At community level the strategies were not strictly speaking technical; at times, however, they call for technical solutions.

Arising from the above, recommendations at household, community, municipal and city level are made.

- A scientific study should be conducted on the technical suitability of the coping strategies at household level, to suggest better ways to improve them. Technical universities and colleges are better placed to do this. This should be followed by deliberate and continuous efforts to impart the newly found knowledge and skills to the residents through user-friendly training methods. Municipal authorities should equally be equipped with the knowledge because success largely depends on their capacity, competence, willingness to support and commitment.

- Community level initiatives to control house and warehouse construction in the settlement and across the natural drains should be augmented. Besides this, stormwater drainage channels should be built and regularly maintained. Initiatives to manage solid waste properly should also be promoted. Today more than ever before municipal authorities are requested to be closer to the populations they are supposed to serve. To achieve this they are advised to work with non-governmental organisations and other stakeholders that have proven knowledge of and skills in working with people living in informal settlements and, more specifically, disasterprone areas.

- Mapping of all flood-prone areas in the city should be carried out and continuously updated. The maps should contain detailed information on flooding. Accurate and reliable data can be obtained by actively involving the residents as partners in data collection. Photographs and other user-friendly illustrations could be used. The maps and other materials should be widely disseminated in all the municipalities.

- The municipalities should do all they can to make available large numbers of housing plots located on safer sites for all income groups. The provision of plots to all income groups is meant to tap the potential of cross-subsidies when calculating the price of the plots.

- Finally, the city and municipalities should slowly convert all the existing urban flood-prone areas and valleys into conservation areas. 


\section{Acknowledgements Competing interests}

The authors declare that they have no financial or personal relationship(s) which may have inappropriately influenced them in writing this article.

\section{Authors' contributions}

T.S. (Ardhi University) was responsible for field data collection and both J.L. (Ardhi University) and S.S. (Ardhi University) were the supervisors and study coordinators.

\section{References}

Adelekan, I.O., 2010, 'Vulnerability of poor urban coastal communities to flooding in Lagos, Nigeria', Environment and Urbanization 22(2), 433-450.

Awuor, C.B., Orindi, V.A. \& Adwera, A.O., 2008, 'Climate change and coastal cities: The case of Mombasa Kenya', Environment and Urbanization 20(1), 231-242. $\mathrm{http}: / / \mathrm{dx}$.doi.org/10.1177/0956247808089158

Benevolo, L., 1971, The Origins of Modern Town Planning, MIT Press, Massachusetts.

Blaikie, P., Cannon, T., Davis, I. \& Wisner, B., 2004, At risk: Natural hazards, people's vulnerability and disasters, 2 nd edn. Routledge, London.

Douglas, I., Alam, K., Maghenda, M., Mcdonnell, Y., Mclean, L. \& Campbell, J., 2008, 'Unjust waters: Climate change, flooding and the urban poor in Africa', Environment and Urbanization 20(1), 187-205. http://dx.doi.org/10.1177/0956247808089156

Inter-American Development Bank, 2011, Urban Sustainability in Latin America and the Caribbean, Inter-American Development Bank, Washington, DC.

Jabeen, H., Johnson, C. \& Allen, A., 2010, 'Built-in resilience: Learning from grassroots coping strategies for climate change', Environment and Urbanization 22(2), 415-431.
Kombe, W.J., 1995, Formal and Informal Land Management in Tanzania: The case of Dar es Salaam City, Spring Research Series, Number 13, Dortmund, Germany.

Lerise, F. \& Malele, B., 2005, Community initiatives in managing urbanization and risk accumulation processes: Lessons from Dar es Salaam, Tanzania - Risk accumulation in the development of Msasani Bonde la Mpunga, viewed 15 April 2009, from http://www.undp.org/cpr/disred/documents/regions/africa/AURAN bis/New Msasani Profile.doc

Lupala, J.M., 2002, Urban Types in Rapidly Urbanising Cites, Analysis of Formal and Informal settlements in Dar es Salaam, Tanzania, KTH, Stockholm.

Satterthwaite, D., Huq, S., Pelling, M., Reid, H. \& Lankao, P.R., 2007, 'Adapting to climate change in urban areas: The possibilities and constraints in low- and middle- income nations', Discussion Paper Series: Human Settlement Working Paper, London IIED.

UN-Habitat, 1996, An urbanizing world: Global report on human settlements, Oxford University Press, Oxford.

UN-Habitat, 2003, The challenge of slums, Earthscan, London.

UN-Habitat, 2006, The state of the world's cities report 2006/2007: 30 years of shaping the habitat agenda, Earthscan, London.

UN-Habitat, 2010a, Citywide action plan for upgrading unplanned and un-serviced settlements in Dar es Salaam, UN-Habitat, Nairobi.

UN-Habitat, 2010b, The state of the world's cities report 2010/2011 - Cities for all: bridging the urban divide, Nairobi.

United Republic of Tanzania, 2003, 2002 Population and Housing Census General Report, National Bureau of Statistics, President's Office, Planning and Privatisation, Government Printers, Dar es Salaam, Tanzania.

Van Der Linden, J.P. \& Hanson, C.E. (eds.), 2007, Climate change impacts, adaptation and vulnerability, Cambridge University Press, Cambridge.

World Health Organization, 1993, Drinking Water Quality Guidelines, World Health Organization, Geneva.

World Health Organization, 2008, Our cities, our health our future: Acting on socia determinants for health equity in urban settings, World Health Organization Centre, Kobe. 